\title{
Comparison of the attitudes towards learning with the participation motivation level in e-sports players
}

\section{Esra Bayrak Ayaş}

Department of Physical Education and Sports Teaching, Physical Education and Sports High School, Adıyaman University, Adıyaman, Turkey.

Accepted 4 March, 2020

\begin{abstract}
In our age, developments in modern technology are so fast that even following up is very difficult. These developments affect every field of daily life as well as affecting the sports field, resulting in new progress in this field. Electronic sports, which is abbreviated as e-sports, is one of these developments. E-sports has also recently developed rapidly and has gained popularity especially among young people. This rapid rise and increasing popularity required research on e-sports. From the view of this aspect, in this work, the motivation of the athletes engaged in the e-sports branch as licensed to participate in e-sport and their attitudes towards learning was evaluated in terms of various variables and it was aimed to compare the differences between the two situations. 186 female and 271 male e-sports players voluntarily participated in the study. In the research, "the e-sports Participation Motivation Scale" and "Attitude Scale Regarding Learning" were used. Semantic differences were found in the e-sports participation motivation scale and learning attitude scales of the e-sports players participating in the study. Besides, it has been observed that there is a positive relationship between e-sports players' attitudes towards learning and e-sports participation motivation levels.
\end{abstract}

Keywords: E-sports players, motivation, attitude towards learning.

E-mail: ebayrak@adiyaman.edu.tr; esrabayrak86@gmail.com.

\section{INTRODUCTION}

With the rapid progress of industrialization policy, the information age and urbanization are also progressing. This progress has brought different features in the culture of social life and social structure day by day (Yetim, 2000). All social and economic changes in the mentioned modern age can be seen in sports organizations and organizations (Balcl, 2003). Although sports, which are increasingly accepted as a service sector in society every day, also have protective and developing qualities of individual and community health. The sports sector has made improvements both in the production of services and goods and in their use. As a result of this situation, both business and sports management have become among the research subjects of scientists with their consumption dimensions (Can and Soyer, 2000).

The sports industry is the name given to the market that includes the concepts of fitness, sports, leisure activities and recreation of consumers, and also offers people, services, products, places and thoughts about these concepts (Devecioğlu, 2004). The modern market economy should gradually determine the commodity laws, production-consumption, supply-demand principles, to determine the principles of sports on the one hand and to pave the way for sports (Talimciler, 2002). It is seen that the relationship of the sports industry with the production and consumption units of the sports fields appeals to large areas. As in other sectors, data is the most important source in the sports sector. The bandwidth must be high and available to meet the demands of more than one person at the same time to protect, store and even access the data (Murathan, 2017).

Electronic sports (e-sports), which has a unique audience and has managed to connect millions of spectators to its ecosystem, is shown as a sport that will mark the coming years. Electronic sports can also be 
described as the last point where video games and technology meet. E-sports is a new generation sports activity that includes fair competition elements, can be performed in teams or individually, requires quick reflexes, is played with technological equipment, requires a physical environment, has its own rules and is organized based on online games. E-sports can be defined as a sport that requires both physical and mental effort, bringing people from both ends of the world together by the internet to play games, and even bringing people from different countries around the world to play games by bringing together (Argan et al., 2006).

E-sports is a virtual competition platform where different skills such as hand-eye coordination, reflex, fast and sudden decision making, team and resource management are at the forefront according to the content branches (BTiK- Information and Communication Technologies Authority) (BTIK, 2017).

According to the International Federation of eSports (leSF), eSports is defined as the combination of the words "electronics and sports. E-sports is a competitive sport using information and communication technologies (computers, displays and connections, and other necessary equipment)". As in other sports, e-sports also aim to defeat the opponent. In this process, players mental and physical abilities, controlling the devices used and using a variety of tactics are important parameters.

According to the classification made by the BTIK, esports types are as follows (BTiK, 2017):

- Fight (Tekken, Street Fighter, etc.),

- 1st Person Shooting Games (Counter-Strike, Quake, Overwatch, Zula CrossFire),

- Real-Time Strategy (StarCraft),

- Sports and Racing Games (UFC, Pro Evolution Soccer, FIFA, NBA2K 2017, Fight Night, Trackmania),

- MOBA (Massively Online Battle Arena-Massive Online Battle Arena),

- Others

E-sports stands out as a competitive foundation based on computers, tablets, phones, and various game consoles. It has a structure that can be played as a team or one-onone, depending on the game played (Korpimies, 2017). In general, the direction in which e-sports differs from traditional sports is that competitions are held virtually rather than physically (Laakkonen, 2014). As in traditional sports, e-sports is a platform with its own professional rules. It is a group of organizations organized based on online games and tournament/league systems, where professional e-sports teams and athletes come together within a prize and trophy goal (Gül et al., 2017).

In light of the information mentioned, it is seen that the awareness and effectiveness of e-sports are increasing day by day. This increasing effectiveness of e-sports affects all aspects of daily life as well as the sports field. Due to its increasing significance, it is important to investigate e-sports in many aspects including gender and to consider its results. For these reasons, in this study, the relationship between the motivation of eathletes at the professional level and the concept of learning was investigated. Based on the results of the relationship between the concept of learning and the concept of e-sports, the position of e-sports in terms of increasing learning motivation will be understood. In this respect, this research will fill an important gap in the literature.

\section{MATERIALS AND METHODS}

When the universe consists of many elements, it is necessary to make a judgment by generalizing about this universe by using various scanning models (Karasar 2015). In this study, among these models, the General Scan model, which is the scanning model on the whole universe or a group of samples, was used.

\section{Population and sample}

The research population is composed of athletes who are licensed in the e-sports branch. It is aimed to reach a thousand athletes who registered to the Turkish e-sports federation. For this purpose, these e-athletes were asked to participate directly in this study via e-mail. The athletes who returned to this call participated in the research. Thus, a total of 457 e-sportsmen (186 women and 271 men) who were licensed during the 2019-2020 license season, constituted the sample group. The nations of all athletes participating are Turkish.

\section{Data collection tools}

"E-Sports Participation Motivation Scale" developed by Öz and Üstün (2019) was used to obtain data in the research. The scale consists of 47 items and 5 subdimensions. The scale is a 5-point Likert type scale. The maximum score that can be obtained from the scale is 235 , and the minimum score is 47 . The sub-dimensions of the scale are the leisure time, taxonomic field, competition and success, relational self and competence. Cronbach Alpha coefficient of the scale was determined to be 0.980 as a result of the internal consistency analysis.

In the research, the "Attitude Scale for Learning" was used to determine the attitudes of the individual whose validity and reliability study was carried out by Kara (2010) as another data collection tool. The scale consists of 40 question items and four sub-dimensions (attitudes towards the nature of learning, expectations from learning, openness to learning, and concerns about learning). Cronbach Alpha value showing the internal 
consistency coefficient of the scale was 0.65 and the $\mathrm{KMO}$ value was 0.72 . Also, a personal information form prepared by the researcher was used as a data collection tool to determine the demographic information of the esports players.

The reliability parameters of the participation motivation scale for e-sports were expressed in the study of Öz and Üstün (2019). On the other hand, the reliability studies of the Attitude scale were revealed in the study by Kara (2010).

\section{Statistical analysis}

The information about the personal characteristics of the e-sports players participating in the research are presented in Table 1.

When Table 1 is examined, it is seen that 271 of the highest participation of the e-sports players constituting the study is male, 217 of them are 18 years old and under, 192 of them have monthly income of $1000 \mathrm{TL}$ and below, 192 of them are the longest living city/metropolitan, 229 of them are excluding e-sports. They stated that they are licensed in any sports branch and 181 of them play the e-sports applications with the most computers.

Table 2 shows the results of the t-test conducted to determine the relationship between the gender variables of the e-sports players and the attitude scale regarding learning.

When the data in Table 2 are analyzed, it can be seen that significant differences between the gender factor and the nature of learning ( $\bar{x}$ female $=28.13, \bar{x}$ male $=30.08, \mathrm{t}$ $=-1.89, p<0.05)$, anxiety about learning $(\bar{x}$ female $=$ 37.21, $\bar{x}$ male $=26.88, t=5.13, p<0.05$ ), expectations from learning ( $\bar{x}$ female $=39.03, \bar{x}$ male $=36.28, t=-3.81$, $p<0.05)$ and openness to learning ( $\bar{x}$ female $=47.69$, $\bar{x}$ male $=41.10, t=-6,09, p<0.05$ ) were found.

Table 3 shows the results of the t-test to determine the relationship between the e-sports participants' gender variables and the e-sports participation motivation scale.

It can be seen from Table 3 that significant differences between gender factor and the taxonomic field ( $\bar{x}$ female $=$ 34.22, $\bar{x}$ male $=36.00, \mathrm{t}=3.33, \mathrm{p}<0.05)$, competition and success ( $\bar{x}$ female $=29.55, \bar{x}$ male $=33.61, t=3.41$ ) were found.

Table 4 shows the results of the ANOVA test performed to determine the difference between the e-sports motivation scale scores of the e-sports players who participated in the research according to the reasons for turning to e-sports.

When Table 4 is analyzed, significant differences between the relational ego, competition, and success, which are the sub-dimensions of the motivation scale of e-sports players' participation to e-sport and the reasons for turning to e-sport were found. As a result of the Bonferroni test conducted to determine which groups these semantic differences are, the Technological Tools and Materials (1), which are the reasons for turning to esport, are between the Feeling of Loneliness (3) and Free Time Evaluation (4). the difference was found to favor the Causes of Loneliness Feeling (3) and Free Time Assessment (4).

Table 5 shows the relationship between attitude towards learning and e-sports participation motivation.

When Table 5 is analyzed, it was found that the total scores of the attitude scale of the e-sports players participating in the study between learning and the motivation status of e-sports participation were a strong positive relationship above the middle. Accordingly, as the attitude scores of e-sports players increased, there was an increase in the motivation levels of e-sports participation $(r=0.713)$.

\section{RESULTS AND DISCUSSION}

In this section, while interpreting the results of the findings obtained in comparing the motivation level of participation and learning attitudes in e-sports players, it is compared with the results of similar studies.

The demographic information of the e-sports players participating in the research reached maximum values for the parameters given as follows: 271 men for gender, 217 were 18 years old and under, 183 had secondary education, 192 with monthly income of $1000 \mathrm{TL}$ and under, 192 city for the longest living. 229 Yes, for the question of if you are licensed in another sports branch other than e-sports, 181 computer for the question of which material do you perform e-sports applications with the most (Table 1).

Significant differences were found in all sub-dimensions of attitude scale regarding learning in the t-test results conducted to determine the relationship between esportsmen's gender variables and the attitude scale about learning (Table 2). When we look at which groups result in favor of this semantic difference, it can be seen that it is in favor of men for the nature of learning, which is the subscale of learning attitude scale while it is in favor of women for anxiety about learning, expectations from learning, and openness to learning.

Şişko and Demirhan stated that they found significant differences between the attitude scores of male and female students in their studies in 2002 and this semantic difference resulted in favor of male students (Şişko and Demirhan, 2002). Besides, in the study of Toon and Gench's attitudes towards physical education lesson, which was formed by the sample group of healthy and disabled high school students in 1990, they did not find a significant difference between the attitudes of male and female students. In another study on attitude, it was seen that male students 'attitudes were lower than female students' attitude scores (Hicks et al., 2001).

It has been observed that people perform better in 
Table 1. Personal Characteristics of e-sports players participating in the study $(n=457)$.

\begin{tabular}{lll}
\hline Features of e-sports players & & $\mathbf{N}(\%)$ \\
\hline \multirow{2}{*}{ Gender } & Female & $186(40.76)$ \\
& Male & $271(59.24)$ \\
Age & 18 and under & $217(47.48)$ \\
& Ages 19-23 & $177(38.73)$ \\
& 24 age and above & $63(13.78)$ \\
Educational background & Primary school & $139(30.41)$ \\
& Secondary school & $183(40.04)$ \\
& Undergraduate & $108(23.63)$ \\
Level of income per month & Graduate & $27(5.91)$ \\
& & $192(42.01)$ \\
& 1000 TL and below & $95(20.78)$ \\
The Longest Living Place & $1001-2000$ TL & $87(19.03)$ \\
& $2001-3000$ TL & $83(18.17)$ \\
& 3001 TL and above & $146(31.94)$ \\
Are you licensed from any sports branch other than e-sports? & & $119(26.04)$ \\
& The village/town & $192(42.01)$ \\
& County town & $229(50.10)$ \\
& City & $228(49.89)$ \\
\end{tabular}

Table 2. T-test table of the attitude scale responses regarding learning according to gender status of e-sports players.

\begin{tabular}{llccccc}
\hline Scale dimensions & Gender & $\mathbf{N}$ & $\mathbf{X}$ & $\mathbf{s s}$ & $\mathbf{t}$ & $\mathbf{p}$ \\
\hline \multirow{2}{*}{ The Nature of Learning } & Female & 186 & 28.13 & 3.01 & -1.89 & .01 \\
& Male & 271 & 30.08 & 3.17 & & \\
Anxiety about Learning & Female & 186 & 37.21 & 7.62 & 5.13 & .00 \\
& Male & 271 & 26.88 & 7.03 & & \\
Expectations about Learning & Female & 186 & 39.03 & 4.66 & -3.81 & .00 \\
& Male & 271 & 36.28 & 4.21 & & \\
Openness to Learning & & & & & & \\
& Female & 186 & 47.69 & 6.88 & -6.09 & .00 \\
\hline
\end{tabular}

learning when they have a positive attitude (Braten and Stromso, 2006; Kara, 2010; Duarte, 2007). According to the results of Braten's study on internet-based learning in 2006, it has been concluded that students' attitudes towards learning a topic has a direct effect on their participation in learning activities. Attitudes towards the subject make some students advantageous in learning the subject (Kara, 2010). According to some other studies investigating the effect of attitudes on students 'behaviors, it was concluded that students' feelings, 
Table 3. T-test table of e-sports participation motivation scale responses by e-sports players' gender status.

\begin{tabular}{llccccc}
\hline Scale dimensions & Gender & $\mathbf{N}$ & $\mathbf{~}$ & $\mathbf{s s}$ & $\mathbf{t}$ & $\mathbf{p}$ \\
\hline \multirow{2}{*}{ Taxonomic field } & Female & 186 & 34.22 & 2.68 & \multirow{2}{*}{3.33} & .02 \\
& Male & 271 & 36.00 & 2.87 & & \\
\multirow{2}{*}{ Relational self } & Female & 186 & 21.87 & 4.69 & & \\
& Male & 271 & 26.12 & 6.27 & & .641 \\
\multirow{3}{*}{ Competition and success } & Female & 186 & 29.55 & 3.33 & \multirow{2}{*}{3.41} & .00 \\
& Male & 271 & 33.61 & 3.49 & & \\
Perfection & & & & & & \\
& Female & 186 & 19.19 & 5.22 & \multirow{2}{*}{1.18} & .01 \\
\multirow{2}{*}{ Recreation } & Male & 271 & 25.74 & 4.89 & & \\
& & & & & & \\
& Female & 186 & 17.64 & 4.88 & 2.64 & .510 \\
\hline
\end{tabular}

Table 4. ANOVA test table of e-sports participation motivation scale responses according to the reason for the research group's orientation to e-sports.

\begin{tabular}{|c|c|c|c|c|c|c|c|}
\hline Sub-dimensions & $\begin{array}{ll}\begin{array}{l}\text { Source } \\
\text { variance }\end{array} & \text { of } \\
\end{array}$ & $\begin{array}{c}\text { Sum of } \\
\text { squares }\end{array}$ & Sd & $\begin{array}{l}\text { Average of } \\
\text { squares }\end{array}$ & $\mathbf{F}$ & $\mathbf{P}$ & Significance \\
\hline \multirow{3}{*}{ Taxonomic field } & Between groups & 42.12 & 2 & 21.06 & \multirow{3}{*}{2.39} & \multirow{3}{*}{.22} & \multirow{9}{*}{$\begin{array}{l}\text { Bonferroni } 1-2 \text { responses } \\
\text { were significant in favor } \\
\text { of } 3-4\end{array}$} \\
\hline & In groups & 3663.28 & 455 & 8.05 & & & \\
\hline & Total & 3705.40 & 457 & 8.10 & & & \\
\hline \multirow{3}{*}{ Relational self } & Between groups & 1628.33 & 2 & 814.16 & \multirow{3}{*}{6.11} & \multirow{3}{*}{.01} & \\
\hline & In groups & 20177.15 & 455 & 44.34 & & & \\
\hline & Total & 21805.48 & 457 & 47.71 & & & \\
\hline \multirow{3}{*}{$\begin{array}{l}\text { Competition } \\
\text { success }\end{array}$} & Between groups & 113.80 & 2 & 56.90 & \multirow{3}{*}{3.29} & \multirow{3}{*}{.02} & \\
\hline & In groups & 3681.22 & 455 & 80.90 & & & \\
\hline & Total & 3795.02 & 457 & 8.30 & & & \\
\hline \multirow{3}{*}{ Perfection } & Between groups & 284.03 & 2 & 142.01 & \multirow{3}{*}{4.68} & \multirow{3}{*}{.18} & \\
\hline & In groups & 3977.55 & 455 & 87.41 & & & \\
\hline & Total & 4261.58 & 457 & 9.32 & & & \\
\hline \multirow{3}{*}{ Recreation } & Between groups & 141.82 & 2 & 70.91 & \multirow{3}{*}{3.38} & \multirow{3}{*}{.00} & \\
\hline & In groups & 3354.56 & 455 & 7.37 & & & \\
\hline & Total & 3496.38 & 457 & 7.65 & & & \\
\hline
\end{tabular}

(1) Technological tools and equipment, (2) Circle of friends, (3) Feeling lonely, (4) Recreation. $P<0.05$.

interests, and thoughts about learning a subject affect the behaviors they exhibit (Pierce et al., 2007). Positive attitudes cause students to behave positively towards learning, connect to work, and it increases the efficiency of learning. It is also concluded that students strive to learn the knowledge and skills that are useful in problem solving and daily life, so that they are behavioral, emotional and psychomotor ready to fulfill the requirements of the lesson (Marzano and Pickering, 1997; Tsai and Kuo, 2008). In this context, the study of esports players' attitudes towards learning was carried out in this study. Concerning the attitude towards the nature of learning, results were obtained in favor of male esports players. It was observed that the concerns about learning, expectations from learning and openness to learning resulted in favor of female e-athletes. From this 
Table 5. Correlation between e-sports players' attitudes towards learning and e-sports participation motivation states.

\begin{tabular}{llcc}
\hline & & Attitude towards learning & E-sports participation motivation \\
\hline \multirow{3}{*}{ Attitude towards learning } & Pearson correlation & 1 & $.713\left(^{*}\right)$ \\
& $\mathrm{P}$ & & .000 \\
& $\mathrm{~N}$ & 457 & 457 \\
& & & 1 \\
E-sports participation motivation & $\mathrm{P}$ & $0.713\left(^{*}\right)$ & \\
& $\mathrm{N}$ & .000 & 457 \\
\hline
\end{tabular}

${ }^{*} \mathrm{P}<0.01$

point of view, male e-athletes take a leading position in terms of the nature of learning, while female athletes prioritize anxiety and expectations about the future in the concept of learning.

In the t-test results to determine the relationship between the gender variables of the e-sports players participating in the study and the e-sports participation motivation scale, it was found that significance differences between taxonomic field, competition, success, and competency subscales, which are among the e-sports participation motivation scale subscales, and gender factor (Table 3). When we look at which group this significant difference is in favor of e-athletes, it has been seen that the competence, taxonomic field, competition, and success, which are the sub-dimensions of participation in e-sports, is in favor of men.

As a result of their research, Mustafaoğlu et al. (2018) stated that people who do e-sports as amateur and professional are mostly men and students. In another study on e-sports, it was reported that the vast majority of e-sports people consisted of male athletes and students, and that the rate of e-sports players attending primary, secondary and graduate education was lower than those who attended high school and associate bachelor's degree (Akın, 2008). Argan et al. (2006) also stated that the majority of those interested in e-sports are men.

Bayram (2018) concluded that participation in e-sport is predominantly provided by youth and men in his study on the intention to participate in e-sports tourism within the framework of planned behavioral theory. However, in a study conducted by Duggan (2015) in the United States, it was found that approximately half of the e-sports activities were found to be women.

Significant differences in relational self, competition and success and leisure time sub-dimensions were found in the ANOVA test results which conducted to determine the difference between the groups of the motivation scale scores of participation of e-sports according to the reasons for the orientation towards e-sports (Table 4). As a result of the Bonferroni test conducted to determine which groups favor this significant difference, the Technological Tools and Equipment (1), which is one of the reasons for turning to e-sport, and the Friends Circle (2) are between Feeling of Sense (3) and Free Time
Evaluation (4). It was observed that the difference resulted in favor of Loneliness Feeling (3) and Free Time Evaluation (4) reasons. This result indicates that e-sports players prefer e-sports activities mainly due to the lonely feelings and free time evaluation.

Mustafaoğlu et al. (2018) have been conducted work on e-sports players and according to them the reasons for e-sports players can be listed as playing this sport $(58.3 \%)$, having a career in this field $(32.4 \%)$ and hobby (30.5\%).

In their work, Argan et al. (2006) reported that liking esports is the first among motivating factors that direct people interested in e-sports to such games, while the passion for gaming is in second place and the goal of making money in the last place. Mustafaoğlu et al. (2018), on the other hand, came across the results in the form of passion for playing in the first place, having a career in second place and leisure time in the last place. In Akın's (2008) study, it has been determined that the most important motivating factor in e-sports is entertainment and second place is love for e-sports.

Correlation test to determine the relationship between the attitude scale of e-sports players participating in the study and the motivation status of participation in e-sport results are shown in Table 5. As a result of the correlation test, it was concluded that there is a direct proportion between the attitudes of e-sports players towards learning and the motivation status of participation in esports, that is, the more the attitude scale score on learning has increased, the more it will increase in the motivation scale.

\section{REFERENCES}

Akın, E. (2008). Elektronik spor: Türkiye'deki elektronik sporcular üzerine bir araştırma. (Unpublished MSc Thesis), Eskişehir. Anadolu University Health Science Institute, p. 60.

Argan, M., Özer, A., and Akın, E. (2006). Elektronik spor: Türkiye'deki siber sporcuların tutum ve davranışları. Spor Yönetimi ve Bilgi Teknolojileri Dergisi, 1(2): 1-11.

Balcı, V. (2003). Avrupa Birliği ve Spor. Gazi Beden Eğitimi ve Spor Bilimleri Dergisi, 8(2): 53-66.

Bayram, A. T. (2018). Planlanmış Davranış Teorisi Çerçevesinde Espor Turizmine Katılma Niyeti. Turizm Akademik Dergisi, 2:17-31.

Braten, I., and Stromso, H. I. (2006). Epistemological beliefs, interest, and gender as predictors of internet based learning activities. 
Computer in Human Behavior, 22:1027-1042.

BTIK (Information and Communication Technologies Authority) (2017). Dijital Dünyada Rekabet, e-Spor ve Topluluk Yönetimi Çalıştayı Sonuç Raporu. Bilgi Teknolojileri ve İletişim Kurumu Uluslararası Çocuk ve Bilgi Güvenliği Etkinlekleri Digital Oyunlar Çalıştayları, 10 Ekim 2017, Ankara.

Can, Y., and Soyer, F. (2000). Spor Hizmetlerinde Verimliliği Etkileyen Faktörlerin Değerlendirilmesi. 1.Gazi Beden Eğitimi ve Spor Bilimleri Kongresi, 2: 182-200.

Devecioğlu, S. (2004). Halka Arz Edilen Spor Kulüplerinin Sportif Başarıları İle Piyasa Değerleri Arasındaki İlişki. SPORMETRE Dergisi, 2(1): 11-18.

Duarte, A. M. (2007). Conceptions of Learning and Approaches to Learning in Portuguese Students. Higher Education, 54: 781-794.

Duggan, M. (2015). Gaming and gamers (Research Report). Retrieved from Pew Research Center. Acces Date: 20.01.2020, http://www.pewinternet. org/2015/12/15/gaming-and-gamers/.

Gül, İ. (2017). Fuar Turizmi Kapsamında Oyun Fuarları: Gaming İstanbul Örneği. Gazi Üniversitesi Turizm Fakültesi Dergisi, 2: 106.

Hicks, K., Wiggigns, M., Christ, M., and Mood, F. (2001). Sex differences in grade three students' attitudes toward physical activity. Perceptual Motor Skills, 93: 97-102.

Kara, A. (2010). Öğrenmeye İlişkin Tutum Ölçeğinin Geliştirilmesi. Electronic Journal of Social Sciences, 9:32, 049: 062.

Karasar, N. (2015). Bilimsel Araştırma Yöntemi. Nobel Yayın Dağıtım, Ankara.

Korpimies, S. (2017). Sponsorships in Esports. (Unpublished Thesis, Aalto University, International Business, 2017), p.14.

Marzano, R. J., and Pickering, D. J. (1997). Dimension of Learning Trainer's Manual. Alexandria VI: Mid-Continent Research for Education and Learning.

Murathan, T. (2017). Sporda Yeni Yaklaşımlar, "Güncel Konular ve Yeni Gelişmeler" Part 13: Bilişim Teknolojileri ve Spor (pp. 344-362). Ankara. Gazi Kitabevi.

Mustafaoğlu, R., Zirek, E., and Zeynal, Y. (2018). E-Spor Oyuncularının Demografik Özellikleri, Oyun Oynama Süreleri Ve Başarılarını Etkileyen Faktörler. Journal of Dependence, 19(4): 115122.

Öz, N. D., and Üstün, F. (2019). E-Spor Katılım Motivasyonu Ölçeği'nin (EKMÖ) geçerlik ve güvenirlik çalışması. Türk Spor Bilimleri Dergisi, 2(2): 115-125.

Pierce, R., Stacey, K., and Barkatsas, A. (2007). A scale for monitoring students' attitudes to learning mathematics with technology. Computers and Education, 48: 285-300.
Şişko, M., and Demirhan, G. (2002). İlköğretim Okulları ve Liselerde Öğrenim Gören Kız ve Erkek Öğrencilerin Beden Eğitimi ve Spor Dersine İlişkin Tutumları. Hacettepe Üniversitesi Eğitim Fakültesi Dergisi, 23: 205-210.

Talimciler, A. (2002). Futbolun Metalaşması. Toplum Bilim Futbol Özel Sayısı, 1:16.

Toon C. I., and Gench, B. E. (1990). Auitudes of handicapped and nonhandicapped high school students toward physical education. Perception Motor Skill, 70(3): 1328-1330.

Tsai, C., and Kuo, P. (2008). Cram school students' conceptions of learning and learning science in Taiwan. International Journal of Science Education, 30(3): 353-375.

Yetim, A. A. (2000). Sporun Sosyal Görünümü, G.Ü, Beden Eğitimi Spor Bilimleri Dergisi, 5(1): 63-72.

Citation: Ayaş, E. B. (2020). Comparison of the attitudes towards learning with the participation motivation level in e-sports players. African Educational Research Journal, 8(1): 83-89. 